\title{
A Comprehensive Insight into the Protein-Surface Biomolecular Interactions on Smart Material: Complex Formation between Smart Polymer and Heme Protein
}

Krishan Kumar, Ritu Yadav and Pannuru Venkatesu*

Department of Chemistry, University of Delhi, Delhi-110 007, India

\section{Synthesis and characterization of poly(N-vinylcaprolactam):}

PVCL was synthesized by solution polymerization of VCL by using AIBN as an initiator.1The stock solution was prepared from $50 \mathrm{~mL}$ of hexane, $0.01 \mathrm{~g}$ of AIBN and $10 \mathrm{~g}$ of N-vinylcaprolactam. $4 \mathrm{~mL}$ portions of this solution were placed in glass tubes and the tubes were sealed by flame without evacuation. The glass tubes were then immersed in an oil bath at $70{ }^{\circ} \mathrm{C}$ and polymerized. After the polymerization, the polymer was precipitated with diethyl ether, filtered and dried under vacuum at $40{ }^{\circ} \mathrm{C}$ to a constant weight. The formation of the PVCL was further confirmed by NMR, IR methods. ${ }^{1} \mathrm{H}-\mathrm{NMR}$ spectra of PVCL are provided in Figure S1. The synthesized PVCL was a white powder type polymer. It was soluble in common organic solvents and water.

Four different peaks were observed in the 1H-NMR spectrum of PVCL. In the PVCL very small change was observed in the chemical shifts of methylene protons, $\left(\mathrm{H}_{\mathrm{a}}, \mathrm{H}_{\mathrm{b}}\right.$ and $\left.\mathrm{H}_{\mathrm{c}}\right)$ in the ring. However, the peaks of the polymer became broader. Moreover, the peaks that belong to vinyl group disappeared. There is a small peak in the spectrum of the PVCL at $7.29 \mathrm{ppm}$. This peak corresponds to the solvent, deuterated chloroform. The ${ }^{1} \mathrm{H}$ NMR spectrum of PVCL exhibited peaks at $4.36 \mathrm{ppm}(1 \mathrm{H},-\mathrm{NCH}-$ of the $\alpha$ position $), 3.1 \mathrm{ppm}\left(2 \mathrm{H},-\mathrm{NCH}_{2}-\right)$, $2.4 \mathrm{ppm}\left(2 \mathrm{H},-\mathrm{COCH}_{2}-\right)$ and $1.65 \mathrm{ppm}\left(6 \mathrm{H},-\mathrm{CH}_{2}-\right.$ of the caprolactam ring, and $2 \mathrm{H},-\mathrm{CH}_{2}-$ of the backbone). It can be concluded from ${ }^{1} \mathrm{H}-\mathrm{NMR}$ spectra investigations that a polymer was successfully achieved and the polymerization proceeded by carbon-carbon double bond opening without any change in the caprolactam ring. 

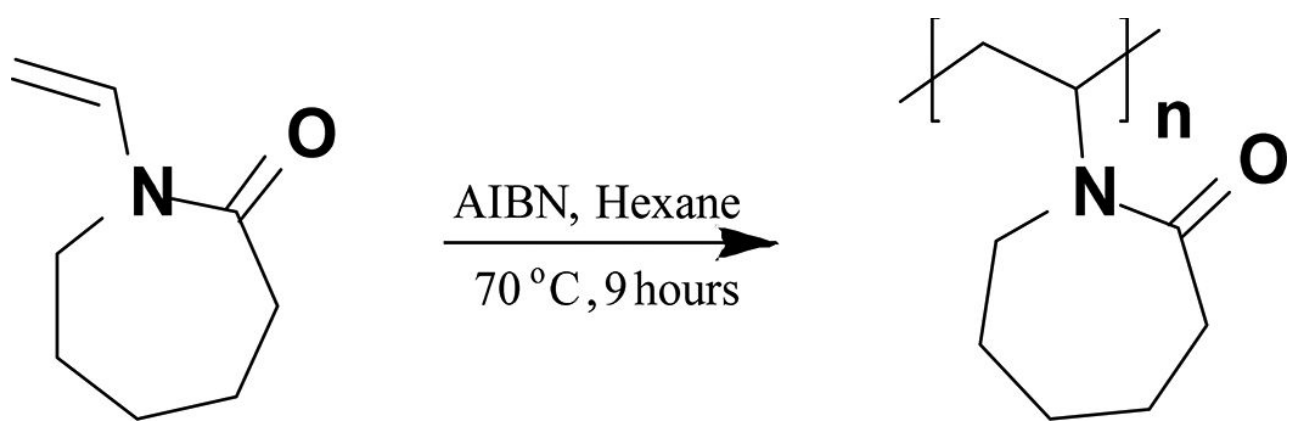

Figure 1S. Synthetic route of PVCL through solution polymerization from VCL in the presence of AIBN as an initiator.

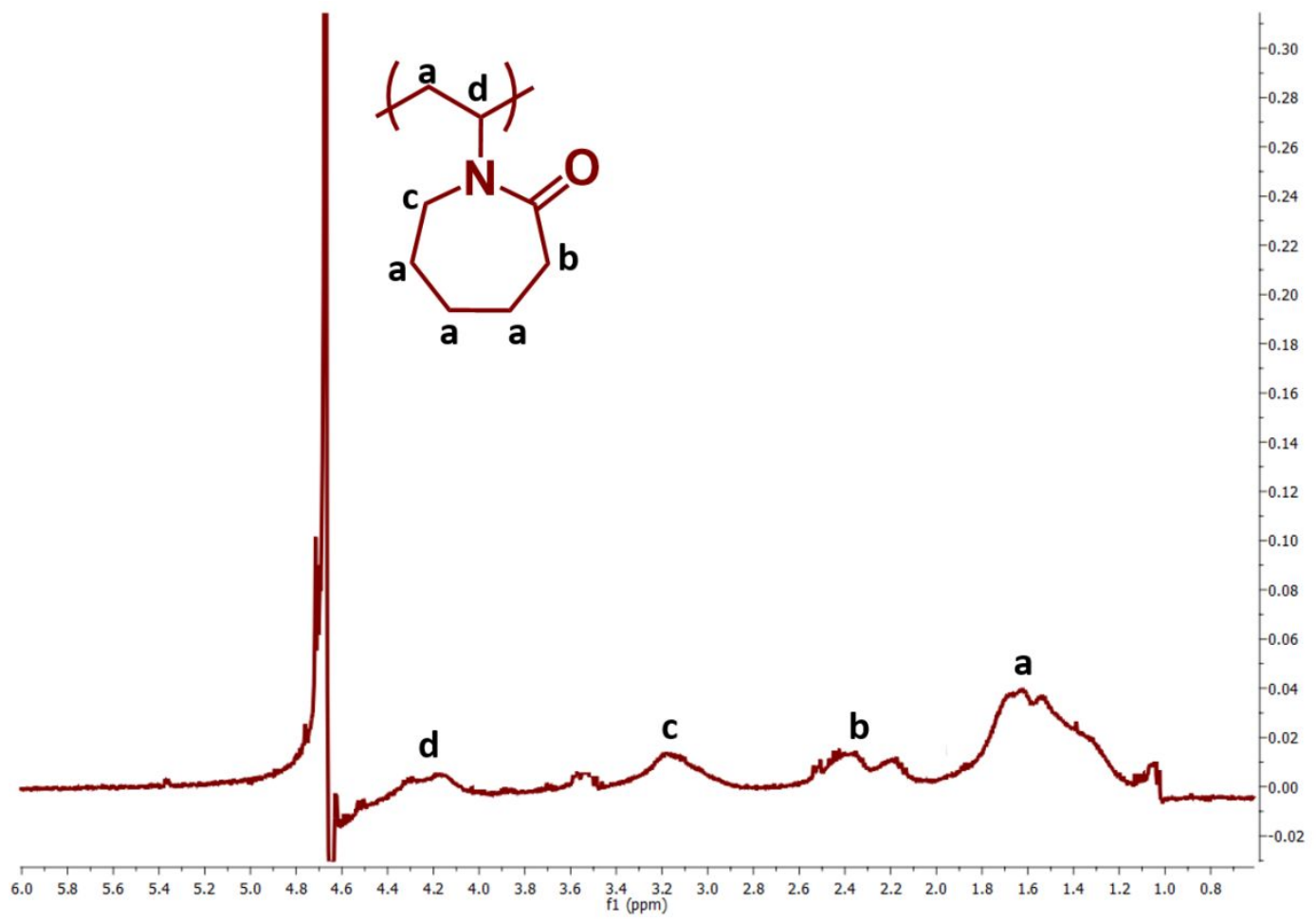

Figure 2S. ${ }^{1} \mathrm{H}-\mathrm{NMR}$ spectrum of PVCL.

\section{Instrumentation Methods:}

The ${ }^{1} \mathrm{H}$ NMR spectra of PVCL were recorded on Jeol Spectrospin spectrometer at $400 \mathrm{MHz}$ and $100 \mathrm{MHz}$, respectively using TMS as an internal standard. The chemical shift values are recorded on $\delta$ scale and the coupling constants $(\mathrm{J})$ are in Hz. Ultraviolet-visible absorption 
spectra of ANS in aqueous PVCL solution in the absence and in the presence of heme proteins were recorded from 250 to $600 \mathrm{~nm}$ by means of a double beam UV-visible spectrophotometer (UV-1800, Shimadzu Co., Japan) at room temperature. Fluorescence intensity measurements of the sample solutions were carried out using a Cary Eclipse fluorescence spectrophotometer (Varian optical spectroscopy instruments, Mulgrave, Victoria, Australia) with an intense Xenon flash lamp as light source. Hydrodynamic diameter $\left(\mathrm{d}_{\mathrm{h}}\right)$ of all samples were measured by using dynamic light scattering (DLS), Zetasizer Nano ZS90 (Malvern Instruments Ltd., UK), equipped with He-Ne (4 mW, 632.8 $\mathrm{nm}$ ). The Fourier transform infrared (FTIR) spectrum was recorded on an iS 50 FT-IR (Thermo-Fisher scientific) spectrometer. The bubble-free samples were placed into an IR cell with two ZnSe windows. A chromel-alumel K-type thermocouple was provided for continuous monitoring of the temperature inside the sample chamber. Each IR spectrum reported here was an average of 200 scans using a spectral resolution of $4 \mathrm{~cm}^{-1}$. Field emission scanning electron microscopy measurements (FESEM) studies were carried out using an MIRA3 TESCAN electron microscope operating at $5 \mathrm{kV}$. All the reported values are an average of three measurements of the sample. Morphological characterization was carried out using TECNAI $200 \mathrm{kV}$ TEM (Fei, Electron Optics) equipped with digital imaging and 35 mm photography system.

\section{Laser Raman spectroscopy measurement:}

A laser Raman spectrometer (renishaw inVia Raman microscope), working in a confocal mode, the inVia is a Raman spectrometer coupled to a microscope was used for the measurement of the Raman spectra. The beam from a $510 \mathrm{~nm}$ HP NIR (high power near IR) diode laser was focused to avoid sample degradation. Raman light was dispersed by using a diffraction grating with 1200 grooves $\mathrm{mm}^{-1}$. Laser power was kept low, ca. $1-3 \mathrm{~mW}$ on the 
sample, to ensure minimal disturbance of the membranes. The desired power was set using the spectrometer software by introducing appropriate filters in the laser beam.

\section{Differential Scanning Calorimetry (DSC) measurements:}

DSC measurements of PVCL in presence of varying concentrations of proteins were performed on NANO DSC instrument. The evaluation of heat flow changes with respect to the change in temperature was performed. Thermal analysis of the all the samples containing PVCL in heme proteins was done in the temperature range 25 to $40{ }^{\circ} \mathrm{C}$ with intervals of 1.0 ${ }^{0} \mathrm{C}$. The experimental conditions involved degassing of the sample solution followed by equilibrating the sample solution at specified temperature and pressure of 3 atm for 600 seconds. Before starting the experiment for polymer, water-water system is performed for baseline correction.
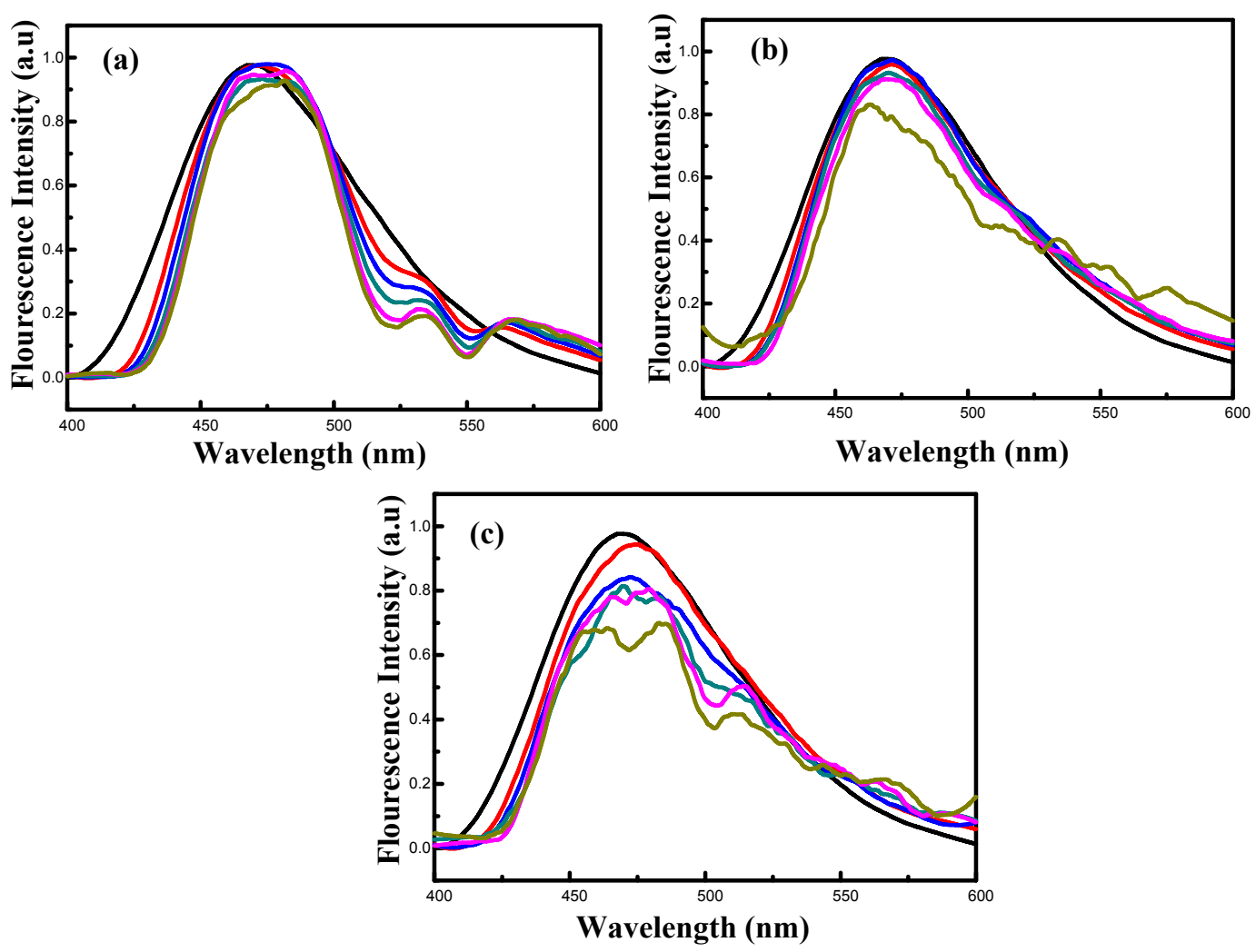
Figure 3S. Normalized fluorescence of ANS in PVCL aqueous solution with and without heme proteins, Protein-free (black line), $0.5 \mathrm{mg} / \mathrm{mL}$ of protein (red line), $1.0 \mathrm{mg} / \mathrm{mL}$ of protein (blue line), $1.5 \mathrm{mg} / \mathrm{mL}$ of protein (cyan line), $2.0 \mathrm{mg} / \mathrm{mL}$ of protein (magenta line) and $2.5 \mathrm{mg} / \mathrm{mL}$ of protein (green line) at $25^{\circ} \mathrm{C}$ (a) Cyt $c$, (b) $\mathrm{Mb}$ and (c) $\mathrm{Hb}$.
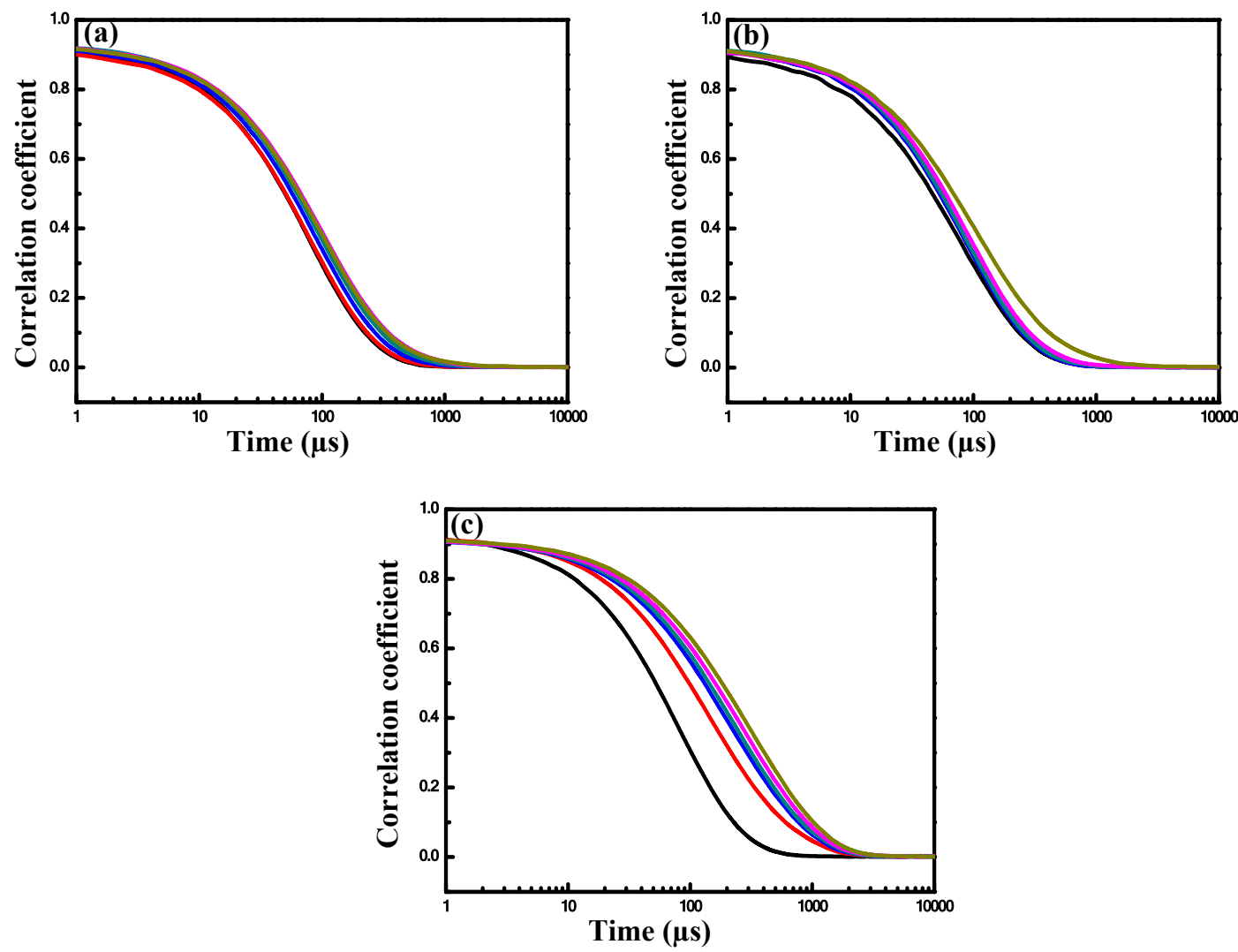

Figure 4S. Variation of correlation coefficient with decay time of PVCL aqueous solution with and without heme proteins, $0.0 \mathrm{mg} / \mathrm{mL}$ (black line), $0.5 \mathrm{mg} / \mathrm{mL}$ of protein (red line), 1.0 $\mathrm{mg} / \mathrm{mL}$ of protein (blue line), $1.5 \mathrm{mg} / \mathrm{mL}$ of protein (cyan line), $2.0 \mathrm{mg} / \mathrm{mL}$ of protein (magenta line) and $2.5 \mathrm{mg} / \mathrm{mL}$ of protein (green line) at $25^{\circ} \mathrm{C} \mathrm{(a)} \mathrm{Cyt} c$, (b) $\mathrm{Mb}$ and (c) $\mathrm{Hb}$. 


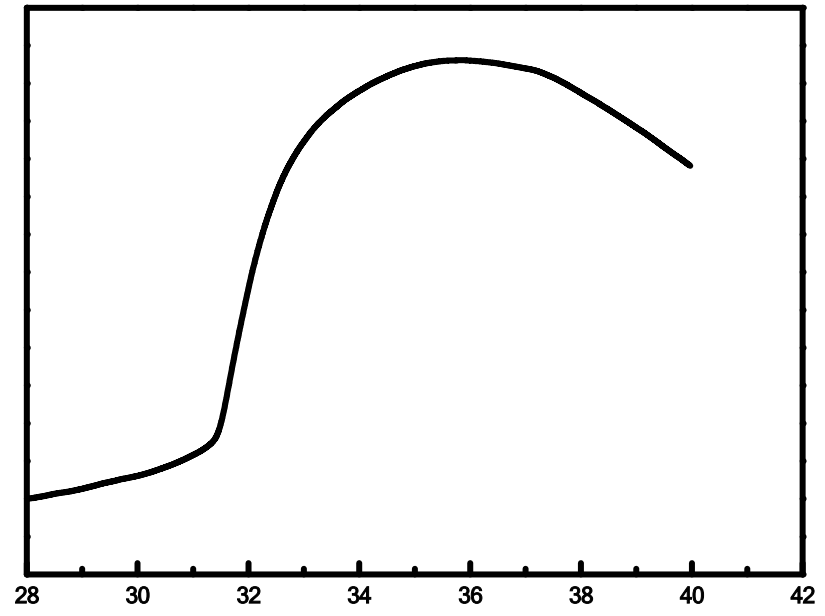

Figure 5S. DSC heating curves of pure PVCL in $\mathrm{H}_{2} \mathrm{O}$ with varying scan rate from 1.0 to 0.05 ${ }^{\circ} \mathrm{C}$. 